\title{
Molecular Cloning of a Bovine Minisatellite DNA Homologous to Mouse Minisatellite
}

\author{
Kazuhiro IKEDA, Ken-ichi TSUTSUMI, \\ Sigeru KIMURA, Sin-ichiro EJIRI, \\ Jutaro TAKAHASHI and Yasuhisa YASUDA \\ Faculty of Agriculture, Iwate University, Morioka-shi 020
}

(Received October 3, 1996)

\begin{abstract}
We have isolated a genomic DNA clone containing a bovine homologue of mouse minisatellite. Southern blot analysis and sequencing revealed that a $6.5 \mathrm{~Kb} B a m H I$ fragment within the clone contained repetitive DNA consisting of tandem repeats with a core sequence GGCTGTGTGT. The cloned bovine minisatellite DNA detected high restriction fragment length polymorphism (RFLP) among individuals when used as a probe, indicating that the probe could be a useful for DNA fingerprinting.
\end{abstract}

Anim. Sci. Technol. (Jpn.) 68 (3) : 293-296, 1997

Key words : Minisatellite, DNA fingerprint, Polymorphism, Bovine

Minisatellite DNA regions of the genome exhibit high length-polymorphism due to a variable number of tandem repeats of a short sequence. These DNA regions were first found in the human genome ${ }^{9)}$ and subsequently in the genomes of other higher eukaryotic species $^{1,6,7,13)}$. Jeffreys et al. ${ }^{10)}$ demonstrated that a DNA 'polycore' probe based on a myoglobin gene minisatellite can simultaneously detect, by hybridization to human genomic DNA, a large number of dispersed hypervariable loci containing tandem repeats of a similar sequence. The complex restriction fragment pattern resulting from such hypervariable loci has been shown to produce a DNA fingerprint specific to an individual. DNA fingerprints can be obtained from a wide range of vertebrates and have many applications including individual identification, paternity testing 3,4,11,13) and linkage analysis $^{2,5,14)}$. Such hypervariable loci might also be useful markers in genetic analysis of domestic animals. Previously, we reported the fingerprint analyses of bovine DNA using mouse minisatellite DNA as a probe ${ }^{8 \text { ) }}$. Here, we report the cloning and structural analysis of a bovine minisatellite DNA, which is consisted of 17 tandem repeats of core sequence GGCTGTGTGT, homologous to the mouse minisatellite.

\section{Materials and Methods}

\section{Construction of genomic DNA library:}

Bovine blood DNA prepared according to the method described by Kunkel et al. ${ }^{15)}$, was partially digested with Sau3AI. DNA ranging

マウスのミニサテライトに相同なウシのミニサテライトDNAのクローニング：池田和博・堤 賢一・林茂・ 江尻慎一郎・高橋寿太郎·安田泰久（岩手大学農学部，盛岡市 020) 


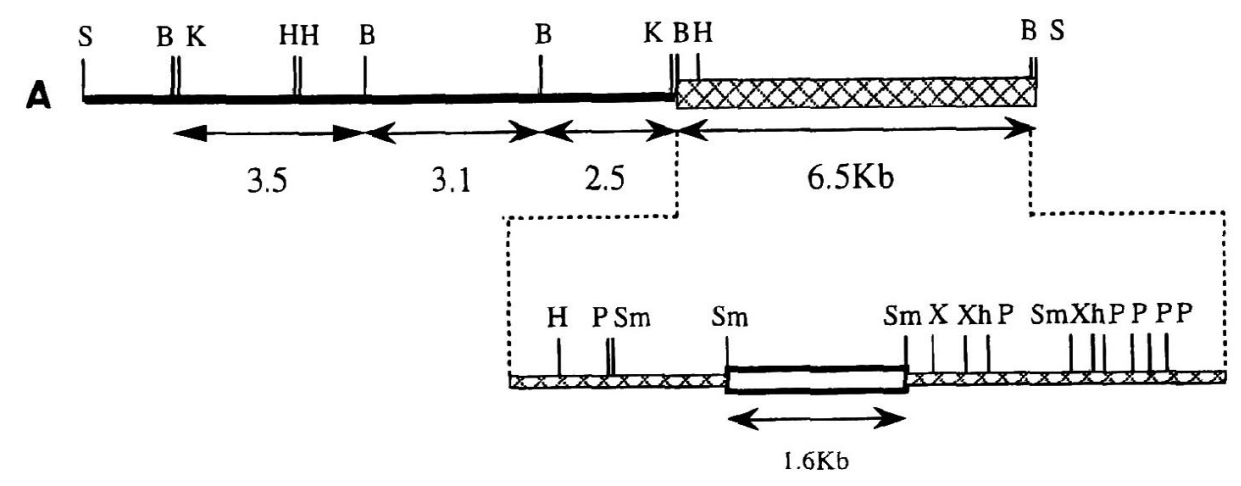

B

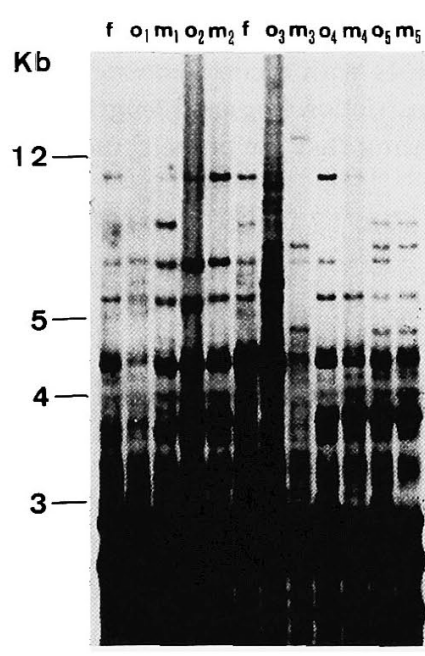

C

GGGCTGCGTGT GGCCGTGTGT GGTTGTGTGT

GGCTGTGTGT

GGCTGTGTGT GGCCGTGTGT GGTTGTGTGT GGCCGTGTGTGT CCTGTGT GCAGTGT GGCTGTGTGT GATGTGTGT GGCCGTGTGT GATTGTGTGT GCCATGTGT GCA

Probe: 6.5

Fig. 1. Restriction map (A), DNA fingerprinting (B), and nucleotide sequence (C) of a bovine minisatellite DNA clone.

(A) Nucleotide length of the Bam $\mathrm{HI}$ fragments of the clone are shown in $\mathrm{Kb}$ below the map. The crosshatched box represents fragment containing a repetitive sequence homologous to mouse minisatellite. Open box which represents a fragment containing a repetitive sequence, was subjected to nucleotide sequencing. Symbols are : B, Bam HI ; H, HindIII ; K, Kpn I ; P, Pst I ; S, Sal I ; Sm, Sma I ; X, Xba I ; Xh, XhoI. (B) DNA fingerprinting using $6.5 \mathrm{~Kb}$ Bam $\mathrm{HI}$ fragment as a probe. DNAs from half-sib pedigrees of Japanese Black cattle were digested with Hin fI, separated on agarose gel, blotted, and hybridized with a labeled $6.5 \mathrm{~Kb}$ Bam $\mathrm{HI}$ fragment. $\mathrm{f}$ denotes the father, $\mathrm{m} 1$ to $\mathrm{m} 5$ are mothers and o1 to o 5 are corresponding offsprings. Size markers are given in $\mathrm{Kb}$.

(C) Nucleotide sequence of an $1.6 \mathrm{~Kb}$ Sma I fragment (open box in a). Highly repeated core sequence which built up the sequence is shown. Variations observed in the core sequence are indicated by small letters. 
from $9 \mathrm{~Kb}$ to $23 \mathrm{~Kb}$ was ligated to phage vector EMBL 3, packaged in vitro using GIGAPACK II GOLD PACKAGING EXTRACT (STRATAGENE) and infected into $E$. coli $\mathrm{LE}$ 392.

The bovine genomic DNA library was screened by hybridization with mouse minisatellite $\mathrm{I}-3-2$ as a probe. The mouse clone I-3-2 was obtained by hybridization with multimerized minisatellite core DNA in an intron of human myoglobin gene (ref. 16 and Kominami and Oyanagi, unpublished data).

Southern blot analysis and DNA fingerprinting:

Individual bovine DNA was digested with Bam HI, electrophoresed on an 1.2\% agarose gel, and blotted overnight onto a nylon membrane. The filter was prehybridized for about $2 \mathrm{hr}$ at $65^{\circ} \mathrm{C}$ in $4 \times \mathrm{SSC}$ containing $1 \%$ SDS, $10 \mathrm{mM}$ Tris $-\mathrm{HCl}, \mathrm{pH} 7.5$ and $10 \mu \mathrm{g} / \mathrm{ml}$ E. coli tRNA, and then hybridized with the labeled probe overnight at $65^{\circ} \mathrm{C}$. Washing was performed twice at $65^{\circ} \mathrm{C}$ in $1 \times \mathrm{SSC}$ containing $0.2 \%$ SDS for 30 min (low stringency) and further washed twice at $65^{\circ} \mathrm{C}$ in $0.1 \times \mathrm{SSC}$ containing $0.2 \% \mathrm{SDS}$ for 30 min (high stringency).

For DNA fingerprinting, $3 \mu \mathrm{g}$ of genomic DNA were digested with HinfI. Hybridization conditions were the same as above, except that washing was carried out under low stringency condition.

\section{Results and Discussion}

From a bovine genomic DNA library, we isolated several clones which hybridized with mouse minisatellite DNA I-3-2. One clone containing an insert of approximately $17 \mathrm{~Kb}$ was analyzed in detail. Figure $1 \mathrm{~A}$ shows the restriction map of the clone. To detect regions showing repetitive sequences in the clone, Southern blot analyses were performed under low and high stringency conditions using $6.5,2.5,3.1$ and $3.5 \mathrm{~Kb}$ Bam HI fragments (designated as probes $6.5,2.5,3.1$ and 3.5 , respectively; see Fig. $1 \mathrm{~A}$ ) as probes. Under low stringency condition, probes $6.5,2.5$ and 3.5 strongly hybridized to multiple fragments of the genome. In contrast, when hybridization was carried out under high stringency, probes 2.5 and 3.5 hybridized only to fragments of comparable sizes expected from the map in Fig. $1 \mathrm{~A}$. On the other hand, the probe 6.5 hybridized to multiple bands even under high stringency concition. Thus, it appears that repetitive sequence (s) within the $6.5 \mathrm{~Kb}$ fragment is dispersed throughout the genome and therefore this fragment is suitable for a multilocus probe. Indeed, the $6.5 \mathrm{~Kb}$ fragment gave typical DNA fingerprints when used as a probe (Fig. 1B).

To detect repetitive region in the $6.5 \mathrm{~Kb}$ fragment, Southern blot hybridization experiments were carried out using various probes obtained from the $6.5 \mathrm{~Kb}$ fragments (Fig. $1 \mathrm{~A}$ ). An $1.6 \mathrm{~Kb}$ SmaI fragment within the $6.5 \mathrm{~Kb}$ DNA (open box in Fig. 1 A) gave multiple bands on Southern blots when used as a probe, showing that this DNA contains a repetitive sequence which is dispersed throughout the genome (data not shown). Part of the nucleotide sequence of the $1.6 \mathrm{~Kb}$ Smal fragment is shown in Fig. $1 \mathrm{C}$. The sequence is comprised of tandemly repeated core sequence GGCTGTGTGT. The observed variations of the core sequence are indicated by small letters in Fig. $1 \mathrm{C}$. It has been reported that minisatellites tend to consist of a $G$-rich sequence ${ }^{12,16,18-21)}$. In this context, the sequence presented here should be the bovine homologue of minisatellite.

\section{References}

1) Coppieters W, Weghe AVD, Depicker A, Bouquet $\mathrm{Y}$, Zeveren AV. A hypervariable pig DNA fragment. Anim. Genet., 21 : 29-38. 1990.

2) Dunnington EA, Gal O, Plotsky Y, Harberfeld A, Kirk T, Goldberg A, Lavi U, Cahaner A, Siegel PB, Hillel J. DNA fingerprints of chickens selected for high and low body weight for 31 generations. Anim. Genet., 21 : 247-257. 1990.

3) Ellegren H, Andersson L, Johansson M, Sandberg $\mathrm{K}$. DNA fingerprinting of horses using a simple (TG)n probe and its application 


\section{IKEDA, TSUTSUMI, KIMURA, EJIRI, TAKAHASHI and YASUDA}

to population comparisons. Anim. Genet., 23 : 1-9. 1992.

4) Georges M, Lequarre AS, Castelli M, Hanset R, Vassart G. DNA fingerprinting in domestic animals using four differentminisatellite probes. Cytogenetics and cell genetics, 47 : 127-131. 1988.

5) Georges M, Lathrop M, Hilbert P, Marcotte A, Schwers A, Swillens S, Vassart G, Hanset R. On the use of DNA fingerprints for linkage studies in cattle. Genomics, $6: 461-474.1990$.

6) Gyllensten UB, Jakobsson $S$, Termin H, Wilson AC. Nucleotide sequence and genomic organization of bird minisatellite. Nucl. Acids Res., $17: 2203-2214,1989$.

7) Hanotte $O$, Burke $T$, Armour JAL, Jeffreys AJ. Hypervariable minisatellite DNA sequences in the Indian Peafowl Pavo cristatus. Genomics, $9: 587-597.1991$.

8) Ikeda $K$, Tsutsumi $K$, Ejiri S, Yasuda Y. DNA fingerprints applied to individual identification and paternity testing in bovines. Anim. Sci. Technol. (Jpn.), 64 : 129-132. 1993.

9) Jeffreys AJ, Wilson V, Thein SL. Hypervariable 'minisatellite' regions in human DNA. Nature, 314:67-73. 1985.

10) Jeffreys AJ, Wilson V. Thein SL. Individualspecific 'fingerprints' of human DNA. Nature, 316: 76-79. 1985.

11) Jeffereys AJ, Morton DB. DNA fingerprints of dogs and cats. Anim. Genet., 18 : 1-15, 1987.

12) Knott J, Wallis SC, Pease RJ, Powell LM, Scott $J$. A hypervariable region $3^{r}$ to the human apolipoprotein B gene. Nucl Acids Res., 14: 9215-9216. 1986.

13) Kominami $R$, Mitani $K$, Muramatsu M. Nucleotide sequence of a mouse minisatellite DNA.
Nucl. Acids Res., $16: 1197.1988$.

14) Kuhnlein U, Dawe Y, Zadworny D, Gavora JS. DNA fingerprinting: a tool for determining genetic distances between strains of poultry. Thor. Appl. Genet., 77 : 669-672. 1989.

15) Kunkel LM, Smith KD, Boyer SH, Borgaonker DS, Wachtel SS, Miller OJ, Breg WR, Jones JR HW, Rary JM. Analysis of human Y-chromosome-specific reiterated DNA in chromosome variants. Proc. Natl. Acad. Sci. USA., 74 : 12451249. 1977.

16) Reeders $\mathrm{ST}$, Breuning $\mathrm{MH}$, Davies $\mathrm{KH}$, Nicholls RD, Jarman AP, Higgs DR, Pearson PL, Weatherall DJ. A highly polymorphic DNA marker linked to adult polycystic kidney on chromosome 16. Nature, 317 : 542-544. 1985.

17) Sanger FS, Nicklen S, Coulson SA. DNA sequencing with chain terminating inhibitors. Proc. Natl. Acad. Sci. USA., 74 : 5463-5467. 1977.

18) Shin HS, Bargiello TA, Clark BT, Jackson FR, Young MW. An unusual coding sequence from a Drosophila clock gene is conserved in vertebrates. Nature, $317: 445-448.1985$.

19) Stocker NG, Cheah KSE, Griffin JR, Solomon ES. A highly polymorphic region $3^{\prime}$ to the human type collagen gene. Nucl. Acids Res., $13: 4613-4622.1985$.

20) Vassert G, Georges M, Monieur R, Brocas A, Lequarre $S$, Christophe D. A sequence in $M 13$ phage detects hypervariable minisatellites in human and animal DNA. Science, 235 : 683-684. 1987.

21) Wong $Z$, Wilson V, Patel I, Povey S, Jeffreys AJ. Characterization of a panel of highly variableminisatellites cloned from human DNA. Ann. Hum. Genet., 51 : 269-288. 1987. 